\title{
Brave New Worlds, Capabilities and the Graduates of Tomorrow
}

\section{Agnes Bosanquet}

MACQUARIE UNIVERSITY

'The principle of sleep-teaching, or hypnopædia, had been discovered' ... '[But] these early experimenters ... were on the wrong track. They thought that hypnopædia could be made an instrument of intellectual education' ... 'Whereas, if they'd only started on moral education,' said the Director, leading the way towards the door. The students followed him, desperately scribbling as they walked and all the way up in the lift; 'Moral education, which ought never, in any circumstances, to be rational.'

Aldous Huxley, Brave New World ${ }^{1}$

Nationally and internationally, generic capabilities or attributes for university graduates are gaining prominence across the higher education sector. ${ }^{2}$ Statements of graduate capabilities typically focus on the skills, characteristics and knowledge graduates require for participation in the workplace. They may also demonstrate an institution's commitment to ethics, social justice, equity, accessibility, environmental sustainability and internationalisation. Pitman and Broomhall argue that the use of 
the terms 'attributes' or 'capabilities', with an emphasis on abstract concepts rather than readily measurable skills, represents a demonstration of the value of higher education in a context of economic constraints, increasing external quality assurance of universities and greater competitiveness within the sector. ${ }^{3}$ The language used to justify graduate capabilities frequently evokes an apocalyptic view of a future characterised by rapid technological advancement, globalisation, climate change, resource constraints, political instability and social surveillance; and emphasises the need for graduates to possess creativity and flexibility to manage these complexities.

This article draws from previous research on a comparative analysis of Australian university graduate capabilities statements from the last fifteen years to examine the values, beliefs and assumptions embedded in such institutional statements. In this research, still in progress, statements of graduate capability were sorted into three time slices according to the year they were formally adopted by their institution: 1996-2000, 2001-2005 and 2006-2009. In the last five years, there has been a shift in the language describing graduate attributes and the institutional statements justifying their inclusion in the curriculum with a move away from a concentration on the individual student towards a notion of community. Similarly, emphasis has moved, from gaining skills for employability fifteen years ago, to action-based approaches between 2000 and 2005, and finally towards a focus on participation, with a sense of imperative or obligation in the last five years. ${ }^{4}$

Based on these findings, this article asks a number of questions: What types of graduates are being produced by universities? For what purposes? What is the role, if any, of higher education in the development of capabilities such as ethical practice or moral standards? What of the principles that are demonstrated in institutional graduate capabilities? Are these universal values? What relations of power and processes of normalisation underpin capabilities-based curriculum?

These questions of inclusion and participation in higher education are particularly pertinent in the current context in Australia in which terms such as education revolution are increasingly politicised. The Bradley Review into higher education has prompted a major change in student cohort, with a target of a 20 per cent increase in participation from lower socioeconomic status students; higher 
proportions of young people receiving degrees ( 40 per cent of 25 to 34 year olds to hold a bachelor degree or above by 2025); tighter regulatory frameworks and performance-based funding. 5 The Australian government's response, titled Transforming Australia's Higher Education, is explicit in its vision of the purpose of higher education:

Self-fulfilment, personal development and the pursuit of knowledge as an end in itself; the provision of skills of critical analysis and independent thought to support full participation in a civil society; the preparation of leaders for diverse, global environments; and support for a highly productive and professional labour force should be key features of Australian higher education. ${ }^{6}$

These discourses are evident in UNESCO's World Declaration on Higher Education for the 21st Century, which emphasises the role of higher learning and research in the 'cultural, socio-economic and environmentally sustainable development of individuals, communities and nations ... so that our society ... can transcend mere economic considerations and incorporate deeper dimensions of morality and spirituality'. ${ }^{7}$

It is worth reiterating the student cohort of the future: increasing numbers of students from families and communities who may not have participated in higher education in the past; students with disabilities; students from low socio-economic status backgrounds; students balancing study with paid work or caring responsibilities; mature-age students; and external or off-campus students. What will be the impacts of institutional visions of the ideal graduate-and the processes of normalisation and relations of power underpinning the curriculum-for these students? In exploring the values, beliefs and assumptions evident in these statements, this article raises more questions than it answers. Its aim is to reflect, and to prompt reflection, on the complexities of the definition, implementation and evaluation of capabilities-based curriculum in the discipline of cultural studies and in the higher education sector more broadly. In so doing, it responds to the call from Giroux to incorporate cultural studies into the language of educational reform and to stake a place for the discipline, its academics and students in supporting, challenging or subverting institutional practices. ${ }^{8}$ It also picks up Flew's claim that the 'discourse of generic graduate capabilities opens up ... a new space for cultural studies' ${ }^{9}$ 
—WHAT TYPE OF GRADUATES ARE BEING 'PRODUCED' BY UNIVERSITIES? FOR WHAT PURPOSES?

When integrated in curriculum and defined in discipline-specific terms, graduate capabilities offer students an outcome-focused perspective on their whole program of studies. They clarify the aims of curriculum, provide an opportunity to align learning outcomes, teaching and learning activities and assessment tasks, and enable students and teachers to consider the impacts and applications of study beyond life at university. They also communicate the values, skills and knowledge a university seeks to foster to prospective students, employers, and accreditation and quality assurance bodies.

Graduate capabilities can be defined as the qualities, skills and values that students develop during their studies; for Bowden, they determine 'the contribution they are able to make to their profession and as a citizen'.10 In an alternative definition, Stephenson argues that a capability-based approach to curriculum focuses on the capacity of students to act as agents in the determination of their own learning and participation in work and life. He continues with the statement that 'a changing world needs people who can look ahead and act accordingly'; but undermines his earlier open definition of capability with the view that a capable person "has culture, in the sense of being able to "decide between goodness and wickedness or between beauty and ugliness"'.11

There are a number of assumptions embedded in these statements concerning the primacy of the individual, the future of work and life, and the privileging of particular moral and ideological perspectives or values. Note the unchallenged use of the term citizen, the emphasis on a vocational model of higher education, the assumption of universal agreement within the university community and its stakeholders, and the value-laden notion of culture as a judgement. As Jones and Moore argue in relation to the application of competencies in education-that is, checklists of skills that indicate performance, set learning objectives and provide measures for student evaluation of accreditation-graduate capabilities are decontextualised from practice, assumed to represent shared understandings and marked by a neglect of issues of value, power and ideology. 12

A review of the literature around graduate capabilities, and an analysis of statements from universities across Australia demonstrate four broad conceptions of their purpose: employability; lifelong learning; preparing for an uncertain future; 
and acting for the social good.13 First, as demonstrated in Bowden et al.'s definition that emphasises the graduate's role as professional and citizen, an employability focus is evident in this de-identified graduate capability statement:

A graduate of this university will apply content knowledge to solve workplace problems, communicate effectively and pursue excellence in professional practice, commit to social responsibility as a professional within business and industry, and demonstrate international perspectives as a professional.

Bridgstock identifies employability as the main impetus for defining graduate capabilities. ${ }^{14}$ She argues that graduates are increasingly required to self-manage career building within complex environments. Within this framework, graduates are described in relation to employability (making a contribution to a profession) and in terms of an obligation to a state or nation (making a contribution as a citizen).

Second, Pitman and Broomhall argue that lifelong learning underpins the concept of graduate capabilities, and strategically positions universities as the primary locus for the development of skills and knowledge. ${ }^{15}$ For example:

Graduates are expected to be independent self-directed learners with the capacity and motivation for lifelong learning; be aware of how they best learn; possess self-knowledge and the ability to think critically and accurately; and have an understanding of how to apply their knowledge and abilities to many different contexts and fields.

The third category imagines a student entering an unknown and uncertain future. In this context, higher education develops the qualities and characteristics that enable students to manage ambiguity and complexity with flexible and creative problem solving. Graduate capabilities are commonly described in transformational terms, holding the potential to transform the student, curriculum and the future. ${ }^{16}$ Barnett refers to the unknown future as one of 'supercomplexity' in which graduates are witnessing a 'new world order' that challenges their understandings of themselves and their place in the world. ${ }^{17}$ This perspective is evident in the following capability statement:

Our students will enter a globalising world of major environmental change and resource constraints, of scientific and technological advance and ethical challenge, of continuing political instability and possible 
international conflicts, of unlimited creativity and increasing social surveillance.

Fourth, the social good construction of graduate capabilities sees a commitment to social justice as the primary purpose of higher education. Bowden et al. argue that graduate capabilities prepare students to be 'agents of social good'.18 In this context, graduate capabilities invoke a requirement for action within the broader community:

Our graduates embody a distinctive approach and commitment to social justice. When our students graduate, they will be equipped to live, learn, work and contribute globally. They will have been inspired by our internationally-focussed, research-led teaching and wish to use their talents to improve the world.

The above institutional statements represent the values, ideologies and visions of the future of particular institutions at the time of their implementation. They are made meaningful in a complex interaction between sector-wide issues (including the massification or democratisation of higher education; funding pressures; increasing emphasis on measuring the standards and quality of research and teaching); institutional contexts (policy; strategic priorities; curriculum review; academic workforce; student cohort and so on) and what happens in the classroom. The assumption these statements are universal and shared by all members of the university community is troubling. This unease affects the implementation of graduate capabilities, and dilutes their value for engaging in critical discussions about curriculum review and the purposes of higher education.

After more than a decade in which Australian universities have been grappling with generic skills, Barrie concludes that there is a mismatch between the rhetoric of graduate capabilities and the reality of teaching practices and student learning experiences. It seems that there is little evidence of a shared understanding of the outcomes of higher education, and even less of a causal relationship between institutional policy frameworks and students' development of capabilities. ${ }^{19}$

Research has demonstrated that embedding graduate capabilities in day-to-day teaching has been 'sporadic, patchy or lumpy'.20 Harvey and Kamvounias describe the 'success of embedding attributes' (or capabilities) as 'extremely elusive'.21 Radloff et al. identify several reasons for this, including a poorly developed rationale 
for graduate capabilities, lack of ownership and shared understanding by academic staff about how to teach and assess graduate capabilities, and the absence of a critical mass of people with vision, passion and drive who will 'champion' capabilities-based curriculum. ${ }^{22}$

Academic cynicism and resistance towards the articulation and implementation of graduate capabilities has been well documented. Radloff et al. describe academic staff beliefs about graduate capabilities and their impact on assessment in particular, as the 'elephant in the room' influencing staff and student engagement, particularly when curriculum change is implemented at an institutional level (that is, from the 'top down'). ${ }^{23}$ Leathwood and Phillips argue that institutional strategies for learning and teaching-they specify evaluation, but their points apply equally to the articulation of graduate capabilities at an institutional level-come up against beliefs in academic freedom and independence, with curriculum review criticised as 'top-down management imposition, evidence of creeping vocationalism ... [and the] "dumbing down" of the curriculum'. Institutional policies that affect learning and teaching practice are viewed as interfering in academic responsibility for and control over degrees and awards. ${ }^{24}$

With a focus on student technological capability, and a vision of a university of the future, Barnes and Tynan offer a way of thinking through the world envisaged in graduate capabilities statements. Barnes and Tynan utilise the fictional case study of Miranda, a university student in 2012 Britain, who demonstrates the potential of instant messages, podcasts, e-books, email, Skype, Wikipedia and social networks for learning and teaching. Miranda's 'brave new world' was first revealed in Shakespeare's The Tempest in a naive exclamation on seeing a man (other than her father) for the first time, and subsequently populated by Aldous Huxley in the 1930s, who envisaged a dystopia of reproductive technologies and sleep-teaching to program social conformity. Barnes and Tyson's Miranda is not ironically named; instead, she earnestly demonstrates a vision of University 2.0: a digital interconnection between subject, education and technology. Barnes and Tynan's use of the phrase 'brave new world' offers all of the naive exclamation from The Tempest with little of the cautionary irony of Aldous Huxley. ${ }^{25}$ In 'Back to the Future', Bridges writes that individual learners will be situated within a student-centred multimedia and 'multi-layered, multimedia, multi-dimensional learning environment' in which 
they have the power to create their own learning. Bridges refers to the 'anarchic' potential of web-based learning. His vision is one of radical upheaval and transformation with universities no longer in control of higher education curriculum, the construction of knowledge or the awarding of degrees. ${ }^{26}$ Barnes and Tynan similarly refer to the 'revolutionary promise' of technologies and the need to radically and urgently rethink learning and teaching and the university itself before 'a generation of opportunities is lost'.27

These apocalyptic claims have much in common with the vision of graduate capabilities, as demonstrated by Barrie's call to engage with different students in a changing and uncertain world which requires a new model for higher education:

What is needed is not simply more knowledge or new skills; what is needed is a new way of being in the world. This has some fundamental implications for how universities conceive of their educational role and with this some challenges for what we teach and the way we teach it. ${ }^{28}$ Bennett, Maton and Kervin are critical of the sensationalist language, implied threat, and proclamations for profound and urgent change that pervade much of the literature around web 2.0 technologies-and graduate capabilities. ${ }^{29}$ Such approaches detract from more considered, research-based investigations into the possibilities for curriculum review, and the impact of graduate capabilities on students, teachers and universities. There is little evidence for the need to radically 'rethink the concept of the university itself' - no matter how beguiling the notion. ${ }^{30}$

- HOW DOES CULTURAL STUDIES CONSTRUCT STUDENTS? WHAT RELATIONS OF POWER AND PROCESSES OF NORMALISATION UNDERPIN THE 'EDUCATION REVOLUTION' OF CAPABILITIES-BASED CURRICULUM?

Cultural studies, as a field that challenges relations of power, discourses and practices of inclusion and exclusion, locations of knowledge and constructions of subjectivity, offers an ideal space for thinking through graduate capabilities and engaging with the difference and diversity of changing student cohorts. Cultural studies cannot be contained within a single discipline; as Hall puts it, it is 'an adaptation to its terrain'. ${ }^{31}$ Broadly speaking, teaching in cultural studies aims to challenge the ways students see the world by raising awareness of the taken-forgranted in everyday life. Students are invited to analyse the production and performance of their own and others' identity politics. Learning and teaching in 
cultural studies is consistent with Barnett, Parry and Coate's descriptor for arts and humanities curricula: it is weighted towards the domains of knowledge and self (subjectivity) with a smaller action domain. ${ }^{32}$ This is consistent with a developmental or constructivist approach to teaching that focuses on challenging learners to develop increasingly complex ways of thinking, leading to conceptual changes and the creation of knowledge. ${ }^{33}$

As noted earlier, Giroux seeks to integrate cultural studies and educational reform. This is not surprising. Donald notes cultural studies 'grew out of an attempt to reinvent educational institutions in ways that were simultaneously more inclusive socially and more expansive intellectually'. ${ }^{34}$ In a way that both reinforces and challenges the place of cultural studies in educational reform, Hall emphasises its undisciplined nature: the absence of an established body of knowledge and canon ('we were making it up as we went along'); and the challenge to the 'normal pedagogic relation'-evident in the etymology of the term for leading children-of teacher as expert. ${ }^{35}$ As Manathunga, Lant and Mellick put it, pedagogy is redefined in cultural studies to incorporate 'the active, productive power relations between the student, the teacher and knowledge'. 36

Hall also underlines the political imperative of teaching cultural studies:

We were inviting students to do what we ourselves had done: to engage with some real problem out there in the dirty world, and to use the enormous advantage given to a tiny handful of us in the British educational system who had the opportunity to go into universities and reflect on those problems, to spend that time usefully to try to understand how the world worked. ${ }^{37}$

To briefly frame this approach within broader pedagogical theory, teaching and learning styles can be conceptualised in four broad domains: behaviourism (teacher transmits knowledge), cognitivism (teacher facilitates learning), constructivism (teacher collaborates with students to construct knowledge) and the emerging theory of connectivism, where students create knowledge that is mediated by the teacher. ${ }^{38}$ Stephenson notes that capabilities-based curriculum runs counter to a behaviourist or content delivery model of education in which the teacher specifies what is to be learnt and how learning occurs. Within this context, graduate capabilities can only be developed separately from the content of a unit or course; 
Stephenson argues that this results in a fragmented model that separates personal and professional skills development from discipline-specific specialist knowledge. ${ }^{39}$ Jones suggests that graduate capabilities are under-valued because teaching staff see them as outside discipline knowledge and teaching practice and as an addition to the real content of the curriculum rather than an integral part of discipline.40 This assumes that teachers hold a behaviourist approach to teaching and learning. Radloff et al. note that effectively implementing a capabilities-based approach requires academics to reflect on their philosophies of teaching and their role as university teachers, and consider the place that developing students' graduate capabilities has in pedagogy and discipline knowledge. ${ }^{41}$ Implicit in the introduction of a capabilities-based curriculum at most universities is a requirement for academics to reflect on their styles of teaching and the learning approaches of their students.

For cultural studies, this process has its roots in the development of the discipline. Cultural studies demonstrates a strong social reform agenda, in which teaching leads to societal change. Defining this perspective, Pratt, Collins and JarvisSelinger refer to teaching as a collective process that emphasises values and ideologies implicit in texts and social practices and challenges the status quo. Their description of a class mirrors many in cultural studies, in which discussion is focused less on content or the presentation of knowledge, and more on who creates knowledge and for what purposes. In a social reform approach to teaching, 'texts are interrogated for what is said and what is not said; what is included and what is excluded; who is represented and who is omitted from the dominant discourses'. ${ }^{42}$

Skelton reinforces this definition of the social reform perspective, stating that the role of the teacher is to 'disturb the student's current epistemological understandings and interpretations of reality by offering new insights'. This leads to new understandings and constructions of subjectivity, and opens up the possibility for enacting social and political change. ${ }^{43}$ Citing this agenda, Donald asks whether teaching in cultural studies has a social purpose beyond 'producing graduates mature enough, autonomous enough, and well enough rounded to fit easily into the slots awaiting them in the new economy?'44 This question lies at the crux of cultural studies' responses to educational reforms. As well as the possibility that graduate capabilities can open up a new space for cultural studies, as Flew suggests, the 
opposite is also true: cultural studies enables teachers and students to question the role of higher education in the development of capabilities such as ethical practice or moral standards; to interrogate the principles that underpin institutional graduate capabilities; and to challenge whether the values of graduate capabilities are universal, inclusive and consensual.

In 'What is Enlightenment', Foucault writes: 'What is at stake, then, is this: How can the growth of capabilities be disconnected from the intensification of power relations?'45 Following Foucault's line of argument raises a number of critical questions and issues around relations of power and processes of normalisation underpinning graduate capabilities. As shown in the examples above, statements of capabilities present an idealised vision of the values, skills and knowledge that students will develop during their studies, and subsequently contribute to society as a worker and citizen. Students are embedded within an institutional framework of knowledge and power: disciplined; ranked according to capability; circumscribed by institutionally determined learning, teaching and curricula; and presented with an imperative to serve the greater good of humanity.

For Kant, enlightenment offers a way out of 'immaturity', a state characterised by the acceptance of another's authority when autonomous reasoning is needed. Are graduate capabilities preparing students to be 'cogs in the machine'? Do they enable them to 'reason' freely and publicly?46 In other words, how do graduate capabilities move students beyond performing a role in society and having a job to do, towards the capacity to engage with the political sphere? What are the implications for graduates? For academics? For universities? For higher education?

In response to Kant, Foucault argues that Kant offered an answer to the philosophical question of enlightenment that did not focus on the transition to a new world, but instead defined enlightenment as an exit from immature ways of being. For Foucault, enlightenment offers a way of imagining an alternative to the constraints of institutionalised subjectivity. Perhaps this is a way of thinking through graduate capabilities; perhaps they do not herald a brave new world, but offer a way out of the rigidity of discipline(s).

The call to action that Foucault heralds is that students become aware of the way in which subjectivity is constructed through graduate capabilities, and consider alternatives for self-creation-no matter how 'fanciful or ephemeral' the 
possibilities. ${ }^{47}$ Or, as Donald puts it, that students are not taught to be particular types of people, but taught to reflect on how 'things could be otherwise, and to have the intellectual skills and courage to imagine alternatives to this strange, privileged, and uncomfortable present in which we live'. ${ }^{48}$ But, see how dangerously close this is to the self-knowledge, critical thinking, creativity and social engagement of graduate capabilities?

\section{- CONCLUSION}

The circular reasoning of this article has raised critical questions about the values and assumptions that underlie graduate capabilities statements, and their implications for the function of universities, impact on students, and the futures of pedagogy in cultural studies. It has attempted to address the political and ethical dimensions of graduate capabilities and assert the primacy of cultural studies in negotiating and analysing these issues. With its undisciplined history, cultural studies is able to question values, challenge assumptions and offer alternative teaching philosophies, curriculum models and student outcomes. Consistent with a reform approach to education is an engagement with issues of social inclusion for students in the future. This is also a reflection of the critical potential of Foucauldian theory, and an alignment between the promising position of cultural studies and Foucault's reading of enlightenment. The growth of capabilities-based curriculum cannot be disconnected from the risk of intensifying power relations at the levels of government, institution, teacher and student in a rapidly expanding higher education system. The question of whether the critical potential of Foucauldian theory, and cultural theory more generally (as advanced by Hall and Giroux in this paper), is able to be absorbed into the language of graduate capabilities remains (to conflate the words of Hall, Mansfield and Donald) part of the realm of fanciful alternatives in this dirty world.

Agnes Bosanquet is a lecturer in Higher Education Development at Macquarie University. She received her doctorate in cultural studies in 2010. Her research interests encompass academic development; critical theory and difference; feminist 
pedagogy and research methods; gender and education; higher education governance; and the scholarship of learning and teaching.

\section{-NOTES}

${ }^{1}$ Aldous Huxley, Brave New World, Chatto \& Windus, London, 1964, p. 27.

2 See, for example: Simon Barrie, 'A Conceptual Framework for the Teaching and Learning of Generic Graduate Attributes, Studies in Higher Education, vol. 32, no. 4, 2007, pp. 439-58; John Bowden, Gail Hart, Bruce King, Keith Trigwell and Owen Watts, Generic Capabilities of ATN University Graduates, Teaching and Learning Committee, Australian Technology Network, 2002, <http://www.clt.uts.edu.au/ATN.grad.cap.project.index.html>.

3 Tim Pitman and Susan Broomhall, 'Australian Universities, Generic skills and Lifelong Learning', International Journal of Lifelong Education, vol. 28, no. 4, 2009, pp. 439-58.

${ }^{4}$ Agnes Bosanquet, Theresa Winchester-Seeto and Anna Rowe, 'Changing Perceptions Underpinning Graduate Attributes: A Pilot Study', Research and Development in Higher Education: Reshaping Higher Education, vol. 33, 2010, pp. 105-17.

5 Denise Bradley, Peter Noonan, Helen Nugent and Bill Sacles, Review of Australian Higher Education Final Report, Department of Education, Employment and Workplace Relations, Canberra, 2008.

6 Department of Education, Employment and Workplace Relations (DEEWR), Transforming Australia's Higher Education System, Commonwealth of Australia, Canberra, 2009, p. 4.

7 UNESCO, World Declaration on Higher Education for the Twenty-first Century: Vision and Action, 1998, <http://www.unesco.org/education/educprog/wche/declaration_eng.htm>.

${ }^{8}$ Henry Giroux, 'Doing Cultural Studies: Youth and the Challenge of Pedagogy', Harvard Educational Review, vol. 64, no. 3, 1994, pp. 278-309.

9 Terry Flew, 'Creativity, the 'New Humanism' and Cultural Studies', Continuum, vol. 18, no. 2, 2004, p. 170.

10 Bowden, Hart, King, Trigwell and Watts, np.

11 John Stephenson, 'The Concept of Capability and its Importance in Higher Education', in John Stephenson and Mantz Yorke (eds), Capability and Quality in Higher Education, Kogan Page, London, 1998, p. 3.

${ }^{12}$ Lyn Jones and Rob Moore, 'Education, Competence and the Control of Expertise', British Journal of Sociology of Education, vol. 14, no. 4, 1993, p. 387.

13 Bosanquet, Winchester-Seeto and Rowe, p. 106.

${ }^{14}$ Ruth Bridgstock, 'The Graduate Attributes We've Overlooked: Enhancing Graduate Employability through Career Management Skills, Higher Education Research and Development, vol. 28, no. 1, 2009, p. 32. 
15 Pitman and Broomhall, pp. 439-58.

16 John Bowden and Ference Marton, University of Learning: Beyond Quality and Competence in Higher Education, Kogan Page, London, 1998.

17 Ronald Barnett, 'Learning for an Unknown Future', Higher Education Research and Development, vol. 23, no. 3, 2004, p. 248.

18 Bowden, Hart, King, Trigwell and Watts, np.

${ }^{19}$ Simon Barrie, 'Understanding What we Mean by the Generic Attributes of Graduates', Higher Education, vol. 51, 2006, pp. 215-41.

20 Claire Hughes and Simon Barrie, 'Discussion Papers', The National GAP Project, 2009, <http://www.itl.usyd.edu.au/projects/nationalgap/resources/discussionpapers.htm>.

${ }^{21}$ Arlene Harvey and Patty Kamvounias, 'Bridging the Implementation Gap: A Teacher-as-learner Approach to Teaching and Learning Policy', Higher Education Research and Development, vol. 27, no. 1, 2008, p. 34.

22 Alex Radloff, Barbara de la Harpe, Helen Dalton, Jan Thomas and Anne Lawson, 'Assessing Graduate Attributes: Engaging Academic Staff and their Students', ATN Assessment 08: Engaging Students with Assessment, 2008, <http://www.ojs.unisa.edu.au/index.php/atna/article/view/342/279>.

23 Radloff, de la Harpe, Dalton, Thomas and Lawson, np.

${ }^{24}$ Carole Leathwood and David Phillips, 'Developing Curriculum Evaluation Research in Higher Education: Process, Politics and Practicalities, Higher Education, vol. 40, 2000, p. 319.

25 Cameron Barnes and Belinda Tynan, 'The Adventures of Miranda in the Brave New World: Learning in a Web 2.0 Millennium', ALT-J, vol. 15, no. 3, 2007, pp. 189-200.

26 David Bridges, 'Back to the Future: the Higher Education Curriculum in the 21st Century', Cambridge Journal of Education, vol. 30, no. 1, 2000, pp. 37-55.

27 Barnes and Tynan, p. 198.

28 Simon Barrie and Mike Prosser, 'Generic Graduate Attributes: Citizens for an Uncertain Future', Higher Education Research and Development, vol. 23, no. 3, 2004, pp. 243-6.

${ }^{29}$ Sue Bennett, Karl Maton and Lisa Kervin, 'The “Digital Natives” Debate: A Critical Review of the Evidence', British Journal of Educational Technology, vol. 39, no. 5, 2008, pp. 775-86.

30 Barnes and Tynan, p. 198.

31 Stuart Hall, 'The Emergence of Cultural Studies and the Crisis of the Humanities', October, vol. 53, 1990, p. 11.

32 Ronald Barnett, Gareth Parry and Kelly Coate, 'Conceptualizing Curriculum Change', Teaching in Higher Education, vol. 6, no. 4, 2001, pp. 435-49.

33 John Biggs and Catherine Tang, Teaching for Quality Learning at University, McGraw-Hill, Berkshire, 2007.

34 James Donald, 'What's New? A Letter to Terry Flew', Continuum, vol. 18, no. 2, p. 245.

35 Hall, p. 11. 
36 Catherine Manathunga, Paul Lant and George Mellick, 'Imagining an Interdisciplinary Doctoral Pedagogy', Teaching in Higher Education, vol. 11, no. 3, 2006, p. 366.

37 Stuart Hall, p. 17.

38 Cameron Barnes and Belinda Tynan, p. 198.

${ }^{39}$ John Stephenson, p. 7.

${ }^{40}$ Anna Jones, 'Redisciplining Generic Attributes: The Disciplinary Context in Focus', Studies in Higher Education, vol. 34, no. 1, 2009, p. 96.

41 Radloff, de la Harpe, Dalton, Thomas and Lawson, np.

42 Daniel Pratt, John Collins and Sandra Jarvis-Selinger, 'Development and Use of the Teaching Perspectives Inventory', American Educational Research, 2001, <www.teachingperspectives.com>.

${ }^{43}$ Alan Skelton, Understanding Teaching Excellence in Higher Education: Towards a Critical Approach, Routledge, New York, 2005, p. 33.

44 James Donald, p. 243.

45 Michel Foucault, 'What is Enlightenment?', in Paul Rabinow (ed.), Ethics: Subjectivity and Truth Volume 1, Penguin, London, 1997, p. 317.

46 Foucault, p 307.

47 Nick Mansfield, Subjectivity: Theories of the Self from Freud to Haraway, Allen and Unwin, Sydney, 2000, p. 63.

48 Donald, p. 246. 